\title{
EFL Students' Attitudes towards Learning English Language: The Case of Libyan Secondary School Students
}

\author{
Dr. Mohamad Jafre Zainol Abidin \\ School of Educational Studies, Universiti Sains Malaysia, 11800 Penang, Malaysia \\ E-mail: Jafre@usm.my \\ Majid Pour-Mohammadi (Corresponding author) \\ Department of English Translation, Islamic Azad University, Rasht, Iran \\ Tel: 60-17-605-4350 E-mail: majid.pourmohammadi@gmail.com \\ Hanan Alzwari \\ School of Educational Studies, Universiti Sains Malaysia, 11800 Penang, Malaysia \\ E-mail: tataeek@gmail.com
}

\begin{abstract}
Received: July 25, $2011 \quad$ Accepted: August 12, $2011 \quad$ Published: February 1, 2012
doi:10.5539/ass.v8n2p119 URL: http://dx.doi.org/10.5539/ass.v8n2p119
\end{abstract}

The research has partly been financed by the Fellowship Scheme of University of Science Malaysia.

\begin{abstract}
This study investigated Libyan secondary school students' attitudes towards learning English in terms of the behavioral, cognitive and emotional aspects. It also explored whether there is any significant difference in the students' attitudes towards English language based on their demographic profiles i.e., gender, field and year of study. A total of 180 participants in the three study years from three specializations of Basic Sciences, Life Sciences, and Social Sciences took a questionnaire as a measuring instrument. Regarding the three aspects of attitude i.e., cognitive, behavioral, and emotional, the participants showed negative attitudes towards learning English. On the demographic profile, there were statistically significant attitudinal differences regarding gender and field of study but not year of study. Based on the research findings, some recommendations are finally presented.
\end{abstract}

Keywords: EFL learner, Attitude, Language learning, Gender, Field of study, Year of study

\section{Introduction}

It is argued that language learning is regarded as the cornerstone of human existence. Knowing the language can help us to express our opinions, hopes, and even our dreams (Tavil, 2009). In foreign Language learning context, there are various factors that influence the learning process such as motivation, attitudes, anxiety, learning achievements, aptitudes, intelligence, age, personalities, etc. (Gardner, 1960; Lehmann, 2006, cited in Shams, 2008). The matter of learner's attitude is acknowledged as one of the most important factors that impact on learning language (Fakeye, 2010). This study looks into the concept of attitude as one of the major affective factors for success in learning a foreign language. More specifically, it investigates Libyan secondary school students' attitudes towards learning English language, taking into consideration the three aspects of attitude i.e., emotional, cognitive, and behavioral. Additionally, it attempts to determine the influence of students' demographic profile i.e., gender, year and field of study on their attitudes towards learning English.

\subsection{Background of study}

Kara (2009) stated that attitudes towards learning besides opinions and beliefs have an obvious influence on students' behaviors and consequently on their performance. It is argued that those students who possess positive beliefs about language learning have a tendency to increase more positive attitudes towards language learning. 
Conversely, negative beliefs may lead to class anxiety, low cognitive achievement, and negative attitudes (Victori \& Lockhart, 1995). According to Alhmali (2007), the purpose of education in Libya is to obtain high grades and pass the exams. Creativity and understanding the nature of students and their needs are not taken into account. The EFL teachers' role is basically to transmit information to their students effectively. There exists little knowledge about the best strategies to develop the students not just cognitively but also behaviorally and emotionally.

In 2000, the new English curriculum "English for Libya" was implemented. This curriculum represents an outstanding change, compared to the previous one. Textbooks are based on the communicative approach. "The curriculum recommends that English to be used as much as possible by the teachers and students in the classroom." (Orafi \& Borg, 2009). Yet, the new curriculum is not applied as planned mainly because of the obvious differences between the main standards of these books and teachers' beliefs.

Meanwhile, the controversial concern is why some EFL students attain higher grades in English language exams than others who are under the same conditions and situations. The concern on the learners' attitudes towards the target language was emphasized by Gardner (1985). He stated that the learners' attitudes towards learning another language play a key role in enhancing and motivating them to learn that language. This, in turn, affects on their performance, too.

\subsection{Research Questions and Hypotheses}

The research seeks to answer the following questions:

1- What are the attitudes of Libyan secondary school students towards learning English language in terms of their behavioral, cognitive and emotional aspects?

2- Is there any statistically significant difference in Libyan secondary school students' attitudes towards learning English language by gender?

3 Is there any a statistically significant difference in Libyan secondary school students' attitudes towards learning English language by the field of study?

4- Is there any a statistically significant difference in Libyan secondary school students' attitudes towards learning English language by the year of study?

Hence, the addressed hypotheses are:

$H_{0} 1$ : There is not a statistically significant difference in Libyan secondary school students' attitudes towards learning English language by gender.

$H_{0} 2$ : There is not a statistically significant difference in Libyan secondary school students' attitudes towards learning English language by the field of study.

$H_{0} 3$ : There is not a statistically significant difference in Libyan secondary school students' attitudes towards learning English language by the year of study.

\section{Literature Review}

As attitude is one of the key predominant factors for success in language learning, numerous studies have already been conducted in the field of language attitude (Alhmali, 2007; Ghazali et al., 2009). In addition, Saidat (2010) mentions that language attitude research has been considered in the previous 50 years because of the growing relation between the importance of the language use and the nature of individuals.

However, the information concerning the language attitudes of Arab students, especially the Libyan students is not sufficient. For that reason, this study investigates the attitudes of EFL learners towards English language at secondary schools in Libya.

\subsection{Definitions of Attitude}

Researchers in the fields of psychology and education, especially language learning, consider several definitions of attitude which mention different meanings from different contexts and perspectives (Alhmali, 2007). Based on the theory of planned behavior, Montano and Kasprzyk (2008, p. 71) state,

"Attitude is determined by the individual's beliefs about outcomes or attributes of performing the behavior (behavioral beliefs), weighted by evaluations of those outcomes or attributes. Thus, a person who holds strong beliefs that positively valued outcomes will result from performing the behavior will have a positive attitude toward the behavior. Conversely, a person who holds strong beliefs that negatively valued outcomes will result from the behavior will have a negative attitude." 
Gardner (1985) also points out that attitude is an evaluative reaction to some referent or attitude object, inferred on the basis of the individual's beliefs or opinions about the referent. "Attitude is thus linked to a person's values and beliefs and promotes or discourages the choices made in all realms of activity, whether academic or informal." Gardner's argument led Wenden (1991) to present a comprehensive definition of the attitude concept. He classified the term "attitude" into three interrelated components namely, cognitive, affective and behavioral. The cognitive component involves the beliefs, thoughts or viewpoints about the object of the attitude. The affective component refers to the individual's feelings and emotions towards an object, whether he/she likes or dislikes. The behavioral component involves the tendency to adopt particular learning behaviors.

\subsection{Importance of Attitude}

Reid (2003, p. 33) declared, "Attitudes are important to us because they cannot be neatly separated from study." Attitude is considered as an essential factor influencing language performance (Visser, 2008). Achievement in a target language relies not only on intellectual capacity, but also on the learner's attitudes towards language learning. This means that learning language should be approached primarily as a social and psychological phenomenon rather than as a purely academic one. Kiptui and Mbugua (2009, cited in Tella et al, 2010) investigated that negative attitude towards English is the most affective and psychological factor that results in the students' poor performance in English among the secondary schools in Kenya.

\subsection{Language Attitude}

Besides the intellectual perspective, the nature of language learning has psychological and social aspects and depends primarily on the learners' motivation and attitude to learn the target language (Padwick, 2010). Gardner and Lambert (1972) have concluded that the ability of the students to master a second language is not only influenced by the mental competence or, language skills, but also on the students' attitudes and perceptions towards the target language. They also advocated that attitude concept could enhance the process of language learning, influencing the nature of student's behaviors and beliefs towards the other language, its culture and community, and this will identify their tendency to acquire that language.

In 1992, Baker proposed a comprehensive theoretical model, focusing on the importance of conducting attitudinal research in the field of language learning. Baker (1992, p. 9) states that, "In the life of a language, attitudes to that language appear to be important in language restoration, preservation, decay or death." Recently, De Bot et al. (2005) assert that language teachers, researchers and students should acknowledge that high motivation and positive attitude of students facilitate second language learning. Thus, if a learner does not have the interest and tendency in acquiring the target language to communicate with others, this learner will possess a negative attitude and will not be motivated and enthusiastic in language learning. Therefore, learners' attitudes could incorporate in language learning because it may influence their performance in acquiring the target language.

\subsection{Aspects of Language Attitude}

Learning process is regarded as a positive change in the individual's personality in terms of the emotional, psychomotor (behavioral) as well as cognitive domains, since when one has learned a specific subject, he/she is supposed to think and behave in a different manner and one's beliefs have been distinguished (Kara, 2009). Furthermore, learning process has social as well as psychological aspects besides the cognitive approach. Attitude concept can be viewed from these three dimensions. Each one of these dimensions has different features to bring out language attitude results. Accordingly, the attitude concept has three components i.e., behavioral, cognitive and affective. These three attitudinal aspects are based on the three theoretical approaches of behaviorism, cognitivism and humanism respectively. In the following, the three aspects of attitude concept i.e., behavioral, cognitive, and emotional aspects are briefly described.

\subsubsection{Behavioral Aspect of Attitude}

The behavioral aspect of attitude deals with the way one behaves and reacts in particular situations. In fact, the successful language learning enhances the learners to identify themselves with the native speakers of that language and acquire or adopt various aspects of behaviors which characterize the members of the target language community. Kara (2009) stated that,

"Positive attitudes lead to the exhibition of positive behaviors toward courses of study, with participants absorbing themselves in courses and striving to learn more. Such students are also observed to be more eager to solve problems, to acquire the information and skills useful for daily life and to engage themselves emotionally." 


\subsubsection{Cognitive Aspect of Attitude}

This aspect of attitude involves the beliefs of the language learners about the knowledge that they receive and their understanding in the process of language learning. The cognitive attitude can be classified into four steps of connecting the previous knowledge and the new one, creating new knowledge, checking new knowledge, and applying the new knowledge in many situations.

\subsubsection{Emotional Aspect of Attitude}

Feng and Chen (2009) stated that, "Learning process is an emotional process. It is affected by different emotional factors. The teacher and his students engage in various emotional activities in it and varied fruits of emotions are yield." Attitude can help the learners to express whether they like or dislike the objects or surrounding situations. It is agreed that the inner feelings and emotions of FL learners influence their perspectives and their attitudes towards the target language (Choy \& Troudi, 2006).

\subsection{Related Studied}

Many studies have been conducted to explore the nature of students' attitudes towards learning foreign language in general and EFL in particular, compared with the studies concerning the attitudes of ESL learners during the past three decades (Al-Zahrani, 2008). For instance, Shams (2008) conducted a study attempting to investigate students' attitudes, motivation and anxiety towards the learning of English. The findings underlined that the students had affirmative attitudes and high enthusiasm towards English. This also highlighted that most of them showed positive attitudes towards English language and its learning which, in turn, emphasized the value of English language efficiency in the daily life.

Momani (2009) also investigated the secondary stage students' attitudes towards learning English as a foreign language and their achievements in reading comprehension. The findings showed that the respondents had neutral positive attitudes toward learning English. Also, there was a strong correlation between the students' attitudes toward learning English and their performance in reading comprehension.

The findings of study by Al-Tamimi and Shuib (2009) on Petroleum Engineering students' motivation and attitudes towards learning English revealed that they had positive attitudes towards the use of English in the Yemeni social and educational contexts. They also showed affirmative attitude towards the culture of the English speaking world.

In terms of the year of study variable, Al-Zahrani (2008) conducted a study to determine the attitudes of Saudi students towards English. The statistical analysis revealed that there was not any clear difference among the three years in their attitudes towards Learning English as the descriptive statistics showed that the respondents in the three years had the same level of attitude.

Regarding the gender variable, Fakeye (2010) investigated the correlation between attitude and achievement in English among 400 senior secondary students selected randomly from five secondary schools. The findings revealed that there was a significant relationship between attitude and achievement. Additionally, it was explored that students' attitude is not gender-related. Thus, there was not a statistically significant difference in the attitudes of male and female students.

\section{Methodology}

\subsection{Participants}

The participants were 180 students, 94 persons (52.2\%) male and 86 persons (47.8\%) female, randomly chosen from different secondary schools in the division of Al Mergeb, Zliten in the west of Libya. There were 58 students $(32.2 \%)$ in the first year, 68 students (37.8\%) in the second year, and the third year students were $54(30 \%)$. They were from three fields of study: Basic Sciences (BS), Life Sciences (LS), and Social Sciences (SS). There were 58 BS students (32.3\%), 62 LS students (34.4\%), and 60 SS students (33.3\%). As the boys and girls study separately at the secondary stage in the Libyan schools, different schools were chosen to represent both genders' attitudes towards learning English language.

\subsection{Design}

The design of this study is quantitative in nature i.e., descriptive and inferential as well. Thus, an adapted questionnaire was employed as a measuring instrument. The participants were required to answer all the items of the questionnaire honestly, giving their own perceptions about their attitudes towards learning English language in terms of the emotional, cognitive and behavioral aspects of attitude as well as their demographic profile i.e., gender, year and field of study. 


\subsection{Instrument}

The measuring instrument was an attitude questionnaire which focused on the attitudes towards learning English. Additionally, it aimed to explore the differences in the participants' attitudes by their demographic information. The items were partly adapted from the attitude questionnaire test employed in a study by Boonrangsri et al. (2004). Other items were taken from Attitude and Motivation Test Battery (AMTB) designed by Gardner (1985). Furthermore, there were some items based on the researchers' experiences in teaching English (Appendix). On the whole, there were 45 items concerning language attitudes in terms of: behavioral, cognitive, and emotional aspects of attitude. Overall, 30 items were positive and 15 items were negative. The items were put in a 5-point Likert scale from Level 1: Strongly Disagree to Level 5: Strongly Agree.

\subsection{Reliability}

A pilot study was conducted to measure the reliability level of the questionnaire items. To do so, 30 students were randomly selected from the target population. These students did not take part in the actual study. They were required to present their personal information based on the Likert scale of the questionnaire items.

By using The Statistical Package for the Social Science Program (SPSS) version 17.0, an analysis of item reliability was determined through the reliability coefficient test. The acceptable value of Cronbach Alpha was 0.878 which shows acceptable consistency of reliability. This shows that the questionnaire items were completely appropriate for research goals. Table 1 indicates the reliability of the questionnaire items in terms of the three aspects of attitude separately. The value of Cornbach's Alpha regarding the behavioral aspect is 0.731 , the cognitive aspect obtained 0.772, and the Cronbach's Alpha value of the emotional aspect is 0.677.

\subsection{Validity}

To investigate the validity of the questionnaire items, the questionnaire was given to two specialists, a psychologist and an expert in TEFL, chosen from the teaching staff of University of Science Malaysia. Their comments were taken into consideration and they advocated that the items of the questionnaire are valid and reliable to investigate the research objectives.

\subsection{Administration}

English teachers in the chosen schools were required to explain the instructions of the questionnaire form to the participants. Respondents were asked to signify the extent to which they agree or disagree with the items of the questionnaire. The total administration to complete answering the questionnaire lasted about 25 minutes.

\subsection{Data Analysis}

The collected data was analyzed by the SPSS Program aiming to answer the research questions quantitatively. To answer the first research question, descriptive statistics was conducted to determine the frequency, the mean, the variance and the standard deviation of the gathered data. Besides, the independent sample T- test was conducted to answer the second research question. In addition, the One-way ANOVA analysis test was the other type of statistical analysis to examine the third and fourth research questions. The findings are indicated in the next section.

\section{Findings and Discussion}

\subsection{Students' Attitudes towards Learning English Language}

Concerning the first research question, the result of descriptive analysis shows that the overall mean score of English Language Attitude (ELA) among the participants is $2.6167(\mathrm{SD}=0.59177)$. This result reveals that the participants have a negative attitude towards learning English. In addition, the mean scores of the three aspects of attitudes towards English among the respondents differ. As seen in Table 2, the mean score of Behavioral Aspect of Attitude (BAA) is 2.5711 ( $\mathrm{SD}=0.60468$ ), that of the Cognitive Aspect of Attitude (CAA) is 2.6722 ( $\mathrm{SD}=$ 0.63402). Yet, the mean score of responses regarding the Emotional Aspect of Attitude (EAA) is 2.6067 ( $\mathrm{SD}=$ 0.63262 ).

Similarly, Al-Zahrani (2008) reported that most of the participants in his study showed a negative attitude and it was also proposed that the reason of such a negative attitude might have been a reaction to the instructional and traditional techniques used by some of the English language teachers. This is overlapping with the current status of English teaching strategies in the Libyan educational system.

\subsection{The Behavioral Aspect of Attitude towards English Language}

As shown in Table 2, the behavioral aspect of attitude towards English language represents the lowest mean score (2.5711). That is, the participants have negative behavioral attitude and feel not relaxed whenever they have to 
speak in English class. The item "studying English helps me to have good relationships with friends" obtained the second $\operatorname{rank}(\mathrm{M}=2.89, \mathrm{SD}=1.153)$, while the lowest mean score is $(2.22)$ and demonstrates that the participants do not pay any attention when English teacher is explaining the lesson with standard deviation of 1.231 (Table 3). Shams' (2008) study also explored that most of the participants were confused and nervous when they started speaking English in front of other students.

Besides, the results of the current study disclosed that some of the students agreed that they do not pay any attention when English teacher is explaining the lesson. Thus, they show negative behaviors in the English classes. This could be due to the belief among the EFL learners that learning English is not needed and important as other results of this study showed that most of the students never ask their friends or teachers for the homework and what has been taught when they miss the English class $(M=2.27)$ and they put off English homework as much as possible $(\mathrm{M}=2.71)$.

\subsection{The Cognitive Aspect of Attitude towards English Language}

The cognitive aspect represents the highest mean score of attitudes towards English $(M=2.6722, \mathrm{SD}=0.63402)$. The findings indicate that the majority of the respondents showed negative cognitive attitude and agreed that they could not summarize the important points in the English subject content by themselves. This response among the respondents represents the highest mean score 3.02 with $(\mathrm{SD}=1.153)$. This result is similar to the findings of a study by Boonrangsri et al. (2004); the descriptive statistics revealed that 121 participants out of 219 from eight streams of study showed a moderate attitude in their ability to summarize the important points in English subject. Besides, the respondents showed that they could not apply the knowledge from English in their real lives $(\mathrm{M}=2.99$, $\mathrm{SD}=1.081$ ). However, some of them believed that people who speak more than one language are very knowledgeable. This response represented the lowest mean score 2.35 with $(\mathrm{SD}=1.179)$ (Table 4).

\subsection{The Emotional Aspect of Attitude towards English Language}

The responses regarding the emotional aspect of attitude towards English are quite different from those of cognitive aspect and the mean score is $2.6067(\mathrm{SD}=0.63262)$. As can be seen in Table 5 , most of the participants showed that they preferred studying in their mother tongue rather than any other foreign language, representing the highest mean score (3.81) with ( $\mathrm{SD}=1.157)$.

This result is in line with that in Al-Nofaie's (2010) that examined the attitudes of Saudi teachers and students towards using Arabic as a facilitating tool in English classes. It was revealed that the teachers and the students showed generally positive attitudes about using Arabic rather than English language. However, few of the respondents in this study had a positive attitude and wished to speak English fluently. This finding highlights the importance of encouraging the students to participate in collaborative dialogues and activities in which they can acquire the language effectively and this can enhance EFL learners to observe and assess their progress in learning English language.

\subsection{Attitudes towards Learning English regarding Participants' Demographic Profile}

This section discusses whether there is any statistically significant difference in the participants' attitudes towards English in terms of their demographic profile.

\subsubsection{Language Attitudes and Participants' Gender}

The inferential statistical analysis was employed to answer the second question concerning the differences in the participants' attitude towards English by gender variable. The results in Table 6 show that the mean score of language attitude among female students is 2.7599 and standard deviation is 0.54763 while they are 2.4856 and 0.60298 respectively among male students. These descriptive results show that the attitudes of female secondary school students towards English are slightly higher than that of male ones.

The independent sample T-test analysis was carried out to explore the probability of the difference in the participants' attitudes towards English by gender. Table 7 illustrates Levene's Test for Equality of Variances. The SPSS output showed that the p-value was $0.023(F=5.268)$. Since the p-value is less than 0.05 , the assumption of equal variances of the attitude by gender groups was not met. Furthermore, the T-test for Equality of Means was to examine the differences in the participants' attitudes due to gender variable. From the output of SPSS program, it was shown that the p-value was 0.002 i.e., less than 0.05 . Hence, the first research hypothesis was rejected.

These results are in line with those in a study by Shoaib and Dornyei (2005). They advocated that gender is an important perspective under second language learning investigations and concluded that females show more interests, positive behaviors and performances compared with the males. 
The differences between the male and female respondents' attitudes may be due to the diversity of English teaching strategies and classroom activities employed by English language teachers to teach female and male students, on the one hand, and the design and the content of English curriculum may not meet the interests and needs of the male students, on the other hand. So, they do not show a positive reaction towards Learning English.

\subsubsection{Language Attitudes and Participants' Field of Study}

Table 8 indicates that the mean score of attitudes among BS students is $2.4566(\mathrm{SD}=0.52877)$, the mean score of attitudes among LS students is 2.6357 ( $\mathrm{SD}=0.64013$ ), and the mean score of attitudes among SS students is 2.7446 $(\mathrm{SD}=0.56557)$. It is clear that $\mathrm{SS}$ students showed the highest attitudes towards English contrasted with the BS students who indicated the lowest.

The investigation of the probability of the difference in the participants' attitudes towards English regarding their specialization was conducted by using One-way ANOVA test. Table 9 shows the test of homogeneity of variances. The results displayed that the p-value of homogeneity of variances is 0.214 . Thus, the assumption of equal variances is met because p-value is greater than the Alpha level (0.05).

One-way ANOVA analysis was to look into the differences in the attitudes of respondents towards English in terms of their specializations. In Table 10, the SPSS output shows that there is a difference in language attitude among the three groups of specializations $(\mathrm{F}=3.523, \mathrm{p}=0.032<0.05)$. Accordingly, the second research hypothesis is rejected as p-value is less than 0.05 .

So, it is concluded that there is a statistically significant difference in the participants' attitudes towards learning English language regarding the field of study. The analysis of Multiple Comparison was also conducted to determine which groups are statistically different. In Table 11, the Tukey HSD test demonstrates that the statistical difference is significant between SS students and BS students since the $\mathrm{p}$-value is less than Alpha level $(\mathrm{p}=0.025<$ 0.05). Moreover, the mean difference between the two groups of SS students and BS ones is 0.28807 . This result shows that the SS students' attitude towards English is higher than that of BS ones.

These finding are in line with a study conducted by Rad (2009) to probe the English Language Major Student's beliefs and attitudes towards learning English. Regarding the specialization variable, the SPSS results showed that there was a significant difference in the respondents' perceptions about English as a foreign language. It was concluded that Literature students beliefs about three aspects of studying English i.e., aptitude, difficulty, and nature represented higher level than that among Teaching students.

The current research results point that the differences in the attitudes regarding the fields of study may be influenced by the content of the curriculum and the nature of these specializations. The SS students study the social subjects, literature, and languages, while the BS students study mathematics, physics, biology and chemistry. Hence, it is proposed that specialization can influence the nature of attitude towards the subjects in general and English language in particular.

\subsubsection{Language Attitudes and Participants' Year of Study}

Table 12 shows that the attitudes mean scores among first, second and third-year students are 2.6985 (SD= $0.51455), 2.5941(\mathrm{SD}=0.55893)$, and $2.5572(\mathrm{SD}=70107)$ respectively. It can be seen that there is a difference among the three groups in their attitudes towards English. The first year students showed a slightly higher attitude, compared with the other two groups.

The output of homogeneity of variances test was conducted to determine the assumption of equal variances among the three groups of study year variable. Table 13 indicates the p-value is 0.009 which is less than the Alpha value 0.05. Hence, the assumption of equal variances is not met. The analysis of One-way ANOVA was utilized to illustrate the differences in the participants' attitudes towards English regarding their years of study. The SPSS output demonstrates that there is not any difference in the respondents' attitudes towards English due to the year of study variable as the $\mathrm{p}$-value is greater than $0.05(\mathrm{p}=0.419>0.05, \mathrm{~F}=0.875)$. Based on the ANOVA results, it can be said that the third research hypothesis fails to be rejected (Table 14).

Al-Zahrani's (2008) study also revealed similar findings and the descriptive statistics showed that the respondents in the three years had the same level of attitude towards learning English. Perhaps, the result of the current study highlights the similarity in the content and design of English curriculum among the three secondary years in each specialization. Therefore, all secondary students from three years showed no difference in their attitudes towards learning English. 


\section{Recommendations}

Regarding the observed negative attitude towards English, the EFL teachers are recommended to create an encouraging atmosphere in the English classes to promote the students' positive attitudes towards English. They should also motivate the students to learn English, highlighting its importance. This can be achieved by implementing the appropriate methods and activities of teaching English effectively. Furthermore, they should integrate up-to-date materials and supplementary resources in addition to the English text books. This can help them capture students' attention to learn English successfully. Moreover, the EFL teachers should consider the role of gender perspective in language learning, exposing various approaches to improve the students' attitudes, motivation and language performance as well.

They are also recommended to teach the English curriculum as it is supposed to be taught, focusing on the communicative approach. The EFL teachers must be aware that communicative approach encourages EFL learners to collaborate and discuss their experiences and other issues regarding language learning. This can increase their attitude, enthusiasm and their motivation to acquire the language.

Furthermore, curriculum makers should review the content and the design of the curriculum to meet the needs and the interests of the students. They are recommended to consider that the EFL learners have different perceptions about learning other languages due to their differences regarding gender, specialization, year of study, etc. Thus, taking all these issues into account, the curriculum design should be reevaluated so that students could see something different concerning the activities, content, topics, teaching practices etc. and be more motivated to learn English.

\section{Conclusion}

The respondents' obvious negative attitude towards English may lead to conclude that they are not well aware of the importance of English and learn it as a compulsory subject. Briefly, attitude concept is considered as an essential component in language learning. So, a positive attitude should be the umbrella of language learning. EFL teachers should respect and think about students' feelings, beliefs and behaviors before the cognitive abilities. English curriculum and classroom activities should involve affective aims according to the students' needs and their individual differences to build up positive attitudes towards English. It is so important to study learners' personalities. Cognitive performance can be achieved if the EFL learners possess positive attitudes and enjoy acquiring the target language. For that reason, the affective perspective, especially attitude, should be considered in language research.

\section{References}

Alhmali, J. (2007). Student attitudes in the context of the curriculum in Libyan education in middle and high schools. PhD Thesis, University of Glasgow.

Al-Nofaie, H. (2010). Attitudes of Teachers and Students towards Using Arabic in EFL Classrooms in Saudi Public Schools- A Case Study. Research on Youth and Language, 4(1), 64-95. [Online] Available: http://www.novitasroyal.org/Vol_4_1/al-nofaie.pdf (August 9, 2011)

Al-Tamimi, A. \& Shuib, M. (2009). Motivation and attitudes towards learning English: A study of petroleum engineering undergraduates at Hadhramout University of Sciences and Technology. GEMA Online Journal of Language Studies, 9(2), 29-55. [Online] Available: http://www.ukm.edu.my/ppbl/Gema/pp\%2029_55.pdf (August 9, 2011)

Al-Zahrani, M. (2008). Saudi secondary school male students' attitudes towards English: An exploratory study. $J$. King Saudi University, Language and translation, 20, 25-39.

Baker, C. (1992). Attitudes and Language. Clevedon, England: Multilingual Matters.

Boonrangsri, K., Chuaymankhong, D., Rermyindee, N. \& Vongchittpinyo, N. (2004). The Attitude towards English Language Learning of the Students in Vocational Certificate Level under Curriculum in 2002. A Case Study of Ayutthaya Technical College studied by Naresuan University, Thailand.

Choy, S. C. \& Troudi, S. (2006). An investigation into the changes in perceptions of and attitudes towards learning English in a Malaysian college. International Journal of Teaching and Learning in Higher Education, 18(2), 120-130. [Online] Available: http://www.isetl.org/ijtlhe/ (August 9, 2011)

De Bot, K., Lowie, W. \& Verspoor, M. (2005). Second language acquisition: An advanced resource book. London: Routledge. 
Fakeye, D. (2010). Students' Personal Variables as Correlates of Academic Achievement in English as a Second Language in Nigeria. Journal of Social Sciences, 22(3), 205-211.

Feng. R. \& Chen, H. (2009). An Analysis on the Importance of Motivation and Strategy in Postgraduates English Acquisition. English Language Teaching. 2, 93-97. [Online] Available: http://www.ccsenet.org/journal/index.php/elt/article/viewFile/3700/3301 (August 10, 2011)

Gardner, R. \& Lambert, W. (1972). Attitudes and motivation in second language learning. Rowley, MA: Newbury House.

Gardner, R. (1985). Social psychology and second language learning. The role of attitudes and motivation. London: Edward Arnold.

Ghazali, S., Setia, R., Muthusamy, C. \& Jusoff, K. (2009). ESL Students' Attitude towards Texts and Teaching Methods Used in Literature Classes. English language teaching, 2(4), 51-56. [Online] Available: http://www.ccsenet.org/journal/index.php/elt/article/viewFile/4445/3786 (August 10, 2011)

Kara, A. (2009). The Effect of a 'Learning Theories' Unit on Students' Attitudes towards Learning. Australian Journal of Teacher Education, 34(3), 100-113. [Online] Available: http://ro.ecu.edu.au/ajte/vol34/iss3/5 (August 10, 2011)

Momani, M. (2009). The Jordanian Secondary Stage students Achievement in Reading Comprehension according to their views towards Learning English as a Foreign Language. Journal of Human Sciences, 42, 1-36. [Online] Available: http://www.ulum.nl/The\%20Jordanian.pdf (August 11, 2011)

Montano, D. E. \& Kasprzyk, D. (2008). Theory of reasoned action, theory of planned behavior, and the integrated behavioral model. In K. Glanz, B. Rimer \& K. Viswanath (Eds.), Health behavior and health education: Theory, research, and practice. San Francisco, CA: Jossey-Bass, 67-96.

Orafi, S. \& Borg, S. (2009). Intentions and realities in implementing communicative curriculum reform. System, 37, 243-253. http://dx.doi.org/10.1016/j.system.2008.11.004

Padwick, A. (2010). Attitudes towards English and Varieties of English in Globalizing India. University of Groningen. Newcastle, [Online] Available: http://scripties.let.eldoc.ub.rug.nl/FILES/root/Master/DoorstroomMasters/Euroculture/2009/a.m.j.padwick/MA-2 802445-A.Padwick.pdf (August 9, 2011)

Rad, N. (2009). Evaluation of English Students' Beliefs about Learning English as Foreign Language: A Case of Kerman Azad University. International Conference "ICT for Language Learning. 3rd edition. [Online] Available: http://pixel-online.org/ICT4LL2010/common/download/Proceedings_pdf/SLA25-Fatehi_Rad.pdf (August 9, 2011)

Reid, N. (2003). Getting started in pedagogical research in the physical sciences. LTSN Physical Sciences Centre, University of Hull, Hull. [Online] Available: http://hlst.ltsn.ac.uk/assets/ps/documents/practice_guides/ps0076_getting_sarted_in_pedagogic_research_in_the _physical_sciences_aug_2004.pdf(August 9, 2011)

Saidat, A, M. (2010). Language Attitude: The Case of Jordan. International Journal of Academic Research, 2 , 235-243. [Online] Available: http://www.ijar.lit.az/pdf/8/2010\%286-37\%29.pdf (August 11, 2011)

Shams, M. (2008). Students' attitudes, motivation and anxiety towards English language learning. Journal of Research, 2(2), 121-144.

Shoaib, A. \& Dornyei, Z. (2005). Affect in lifelong learning: exploring L2 motivation as a dynamic Process. In P. Benson \& D. Nunan (eds.), Learners' Stories: Difference and Diversity in Language Learning. Cambridge: Cambridge University Press, 22-41.

Tavil, Z. (2009). Parental Attitudes towards English Education for Kindergarten Students in Turkey. Kastamonu Education Journal. 17(1), 331-340. [Online] Available: www.kefdergi.com/pdf/cilt17_no1/331.pdf (August 9, 2011)

Tella, J., Indoshi, F. C. \& Othuon, L. A. (2010). Relationship between students' perspectives on the secondary school English curriculum and their academic achievement in Kenya. Educational Research, 1(9), 390-395. [Online] Available: http://www.interesjournals.org/ER (August 11, 2011)

Victori, M. \& Lockhart, W. (1995). Enhancing metacognition in self-directed language learning. System, 23, 223-234. http://dx.doi.org/10.1016/0346-251X(95)00010-H 
Visser, M. (2008). Learning under conditions of hierarchy and discipline: The case of the German Army (19391940). Learning Inquiry. 2, 127-137. http://dx.doi.org/10.1007/s11519-008-0031-7

Wenden, A. (1991). Learner Strategies for Learner Autonomy. London: Prentice Hall.

\section{APPENDIX}

\section{Questionnaire}

\section{Attitudes of EFL Secondary School Students towards Learning English Language}

Dear student,

The main goal of this study is to investigate attitudes of Libyan secondary school students towards learning English language in terms of the behavioral, cognitive and emotional aspects of attitude. Also this study aims to explore whether there is any significant difference in Libyan secondary school students' attitudes towards learning English language according to their demographic profile i.e. gender, field of study and year of study. Your answers will help EFL teachers and educators to understand EFL learners' needs and overcome any difficulties and challenges they may have with English language.

\section{Part One: Demographic Profile}

Please read the statements below carefully and select the appropriate choices.

\section{A) Gender:}

1. Female

2. Male

B) Specialization:

1. Basic Sciences

2. Life Sciences

3. Social Sciences

\section{C) Year of study:}

\section{First year}

2. Second year

\section{Third year}

\section{Part Two: Attitudes towards English Language}

To what extent do you agree with the following items? The following items ask about your attitudes toward learning the English language. Remember there is no right or wrong answers; just answer as accurately as possible. Please read the statements below carefully and tick the appropriate choices that reflect your attitudes and perceptions towards English language. Use the scale below to answer the questionnaire items.

1= Strongly Disagree $\quad 2=$ Disagree $\quad 3=$ Neutral $\quad 4=$ Agree $\quad 5=$ Strongly Agree .

Note: Tick $(\sqrt{ })$ only one option for each item in the questionnaire.

\begin{tabular}{|l|l|l|l|l|l|l|}
\hline No & Items & $\begin{array}{l}1 \\
\text { SD }\end{array}$ & $\begin{array}{l}3 \\
\text { D }\end{array}$ & $\begin{array}{l}4 \\
\text { N }\end{array}$ & A & SA \\
\hline 1 & Studying English is important because it will make me more educated & & & & & \\
\hline 2 & Being good at English will help me study other subjects well & & & & & \\
\hline 3 & I feel proud when studying English language & & & & & \\
\hline 4 & I feel excited when I communicate in English with others & & & & \\
\hline 5 & Speaking English anywhere makes me feel worried & & & & \\
\hline 6 & Studying English helps me to have good relationships with friends & & & & & \\
\hline
\end{tabular}




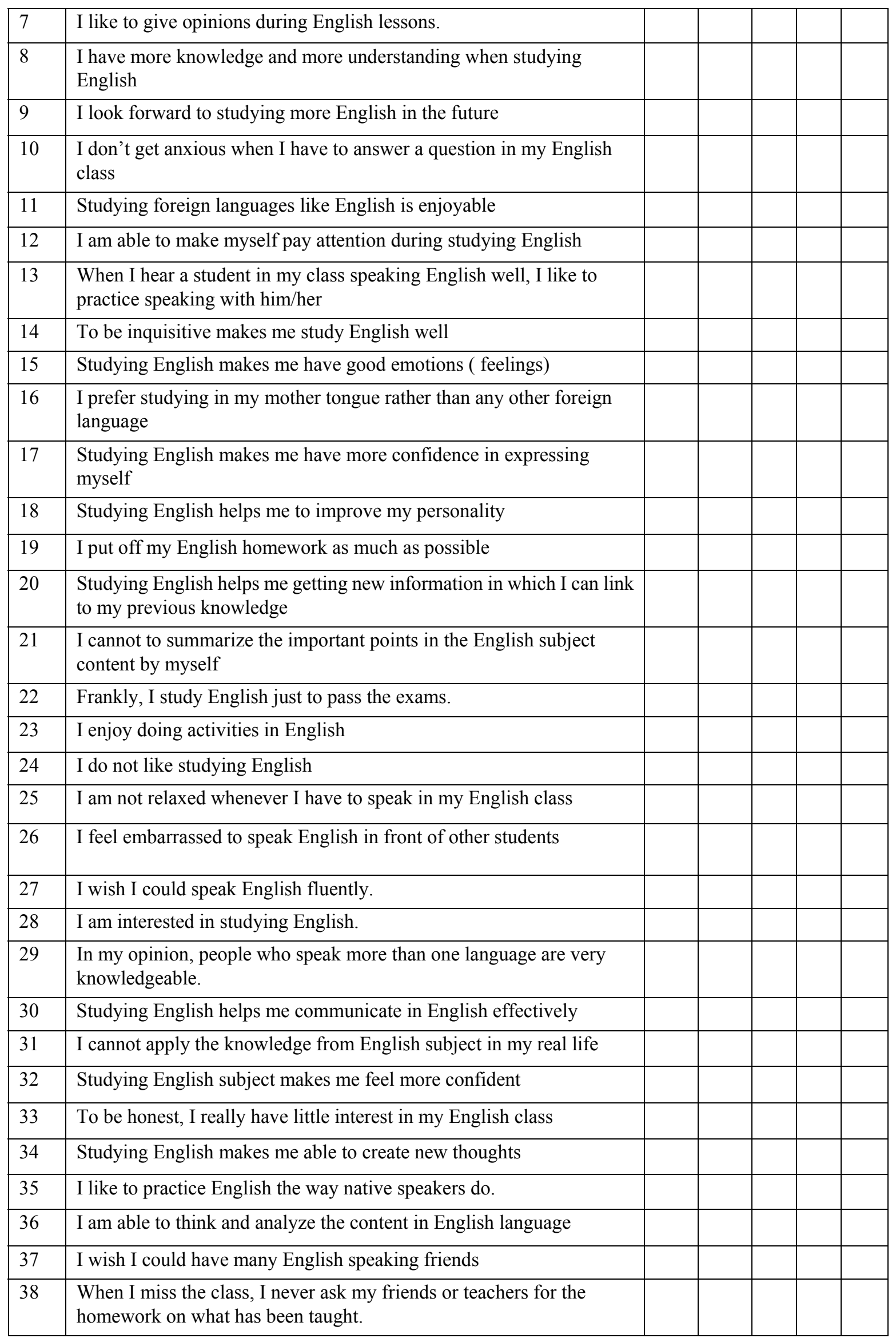




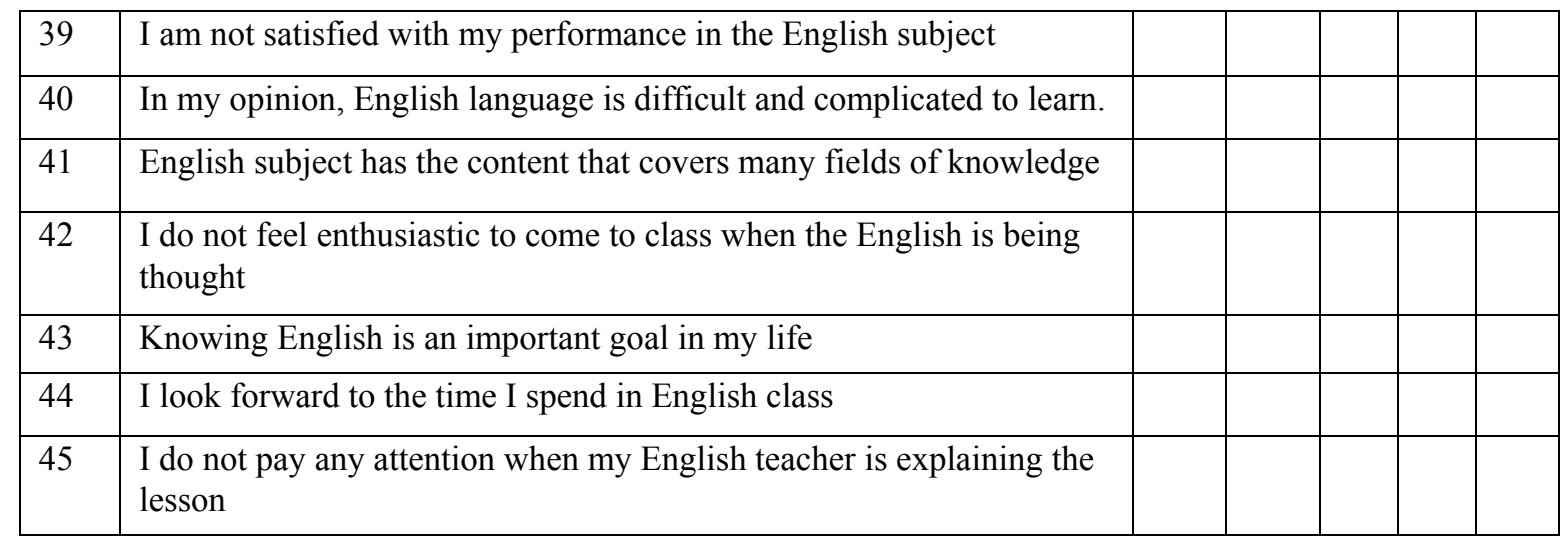

Table 1. Reliability Value regarding the Language Aspects

\begin{tabular}{lll}
\hline Aspects of Attitude & No. of Items & Cronbach's Alpha Value \\
\hline Behavioral aspect & 15 & 0.731 \\
Cognitive Aspect & 15 & 0.772 \\
Emotional Aspect & 15 & 0.677 \\
$\begin{array}{l}\text { General Attitude towards English } \\
\text { language }\end{array}$ & 45 & 0.878 \\
\hline
\end{tabular}

Table 2. Descriptive Statistics of Students' Attitudes towards English Language

\begin{tabular}{llllll}
\hline & $\mathrm{N}$ & Minimum & Maximum & Mean & Std. Deviation \\
\hline ELA & 180 & 1.24 & 3.91 & 2.6167 & 0.59177 \\
BAA & 180 & 1.33 & 3.87 & 2.5711 & 0.60468 \\
CAA & 180 & 1.07 & 4.00 & 2.6722 & 0.63402 \\
EAA & 180 & 1.33 & 4.40 & 2.6067 & 0.63262 \\
Valid N & 180 & & & & \\
\hline
\end{tabular}

Table 3. Descriptive Statistics of Behavioral Aspect of Language Attitude

\begin{tabular}{|l|l|l|l|l|l|l|}
\hline $\begin{array}{l}\text { Behavioral aspect of attitude } \\
\text { Speaking English anywhere makes me feel worried. }\end{array}$ & N & Min & Max & Mean & $\begin{array}{l}\text { Std. } \\
\text { Deviation }\end{array}$ & Variance \\
\hline $\begin{array}{l}\text { Studying English helps me to have good relationships } \\
\text { with friends. }\end{array}$ & 180 & 1 & 5 & 2.63 & 1.103 & 1.217 \\
\hline I like to give opinions during English lessons. & 180 & 1 & 5 & 2.42 & 1.108 & 1.229 \\
\hline $\begin{array}{l}\text { I am able to make myself pay attention during studying } \\
\text { English. }\end{array}$ & 180 & 1 & 5 & 2.54 & 0.971 & .942 \\
\hline $\begin{array}{l}\text { When I hear a student in my class speaking English } \\
\text { well, I like to practice speaking with him/her. }\end{array}$ & 180 & 1 & 5 & 2.31 & 1.125 & 1.266 \\
\hline
\end{tabular}




\begin{tabular}{|l|l|l|l|l|l|l|l|}
\hline $\begin{array}{l}\text { Studying English makes me have more confidence in } \\
\text { expressing myself. }\end{array}$ & 180 & & & 2.87 & 1.020 & 1.039 \\
\hline Studying English helps me to improve my personality. & 180 & 1 & 5 & 2.76 & 1.193 & 1.423 \\
\hline I put off my English homework as much as possible. & 180 & 1 & 5 & 2.71 & 1.141 & 1.302 \\
\hline $\begin{array}{l}\text { I am not relaxed whenever I have to speak in my } \\
\text { English class. }\end{array}$ & 180 & 1 & 5 & 3.17 & 1.022 & 1.045 \\
\hline $\begin{array}{l}\text { I feel embarrassed to speak English in front of other } \\
\text { students. }\end{array}$ & 180 & 1 & 5 & 2.81 & 1.204 & 1.450 \\
\hline I like to practice English the way native speakers do. & 180 & 1 & 5 & 2.23 & 1.233 & 1.521 \\
\hline I wish I could have many English speaking friends. & 180 & 1 & 5 & 2.36 & 1.071 & 1.147 \\
\hline $\begin{array}{l}\text { When I miss the class, I never ask my friends or } \\
\text { teachers for the homework on what has been taught. }\end{array}$ & 180 & 1 & 5 & 2.27 & 1.275 & 1.627 \\
\hline $\begin{array}{l}\text { I do not feel enthusiastic to come to class when the } \\
\text { English is being thought. }\end{array}$ & 180 & 1 & 5 & 2.37 & 1.051 & 1.105 \\
\hline $\begin{array}{l}\text { I do not pay any attention when my English teacher is } \\
\text { explaining the lesson. }\end{array}$ & 180 & 1 & 5 & 2.22 & 1.231 & 1.515 \\
\hline Valid N & 180 & & & & & \\
\hline
\end{tabular}

Table 4. Descriptive Statistics of Cognitive Aspect of Language Attitude

\begin{tabular}{|c|c|c|c|c|c|c|}
\hline Cognitive aspect of attitude & $\mathrm{N}$ & Min & Max & Mean & $\begin{array}{l}\text { Std. } \\
\text { Deviation }\end{array}$ & Variance \\
\hline $\begin{array}{l}\text { Studying English is important because it will make me } \\
\text { more educated. }\end{array}$ & 180 & 1 & 5 & 2.59 & 1.285 & 1.651 \\
\hline $\begin{array}{l}\text { Being good at English will help me study other subjects } \\
\text { well. }\end{array}$ & 180 & 1 & 5 & 2.79 & 1.114 & 1.240 \\
\hline $\begin{array}{l}\text { I have more knowledge and more understanding when } \\
\text { studying English. }\end{array}$ & 180 & 1 & 5 & 2.61 & 1.043 & 1.088 \\
\hline $\begin{array}{l}\text { I like my English class so much; I look forward to } \\
\text { studying more English in the future. }\end{array}$ & 180 & 1 & 5 & 2.46 & 1.159 & 1.344 \\
\hline $\begin{array}{l}\text { Studying English helps me getting new information in } \\
\text { which I can link to my previous knowledge. }\end{array}$ & 180 & 1 & 5 & 2.42 & 1.057 & 1.117 \\
\hline $\begin{array}{l}\text { I cannot summarize the important points in the English } \\
\text { subject content by myself. }\end{array}$ & 180 & 1 & 5 & 3.02 & 1.153 & 1.329 \\
\hline Frankly, I study English just to pass the exams. & 180 & 1 & 5 & 2.59 & 1.298 & 1.685 \\
\hline $\begin{array}{l}\text { In my opinion, people who speak more than one language } \\
\text { are very knowledgeable. }\end{array}$ & 180 & 1 & 5 & 2.35 & 1.179 & 1.391 \\
\hline $\begin{array}{l}\text { Studying English helps me communicate in English } \\
\text { effectively. }\end{array}$ & 180 & 1 & 5 & 2.45 & 1.159 & 1.344 \\
\hline
\end{tabular}




\begin{tabular}{|l|l|l|l|l|l|l|l|l|}
\hline $\begin{array}{l}\text { I cannot apply the knowledge from English subject in my } \\
\text { real life. }\end{array}$ & 180 & 5 & 2.99 & 1.081 & 1.168 \\
\hline Studying English makes me able to create new thoughts. & 180 & 1 & 5 & 2.83 & 1.170 & 1.369 \\
$\begin{array}{l}\text { I am able to think and analyze the content in English } \\
\text { language. }\end{array}$ & 180 & 1 & 5 & 2.64 & 0.967 & 0.934 \\
\hline $\begin{array}{l}\text { I am not satisfied with my performance in the English } \\
\text { subject. }\end{array}$ & 180 & 1 & 5 & 2.97 & 1.246 & 1.552 \\
\hline $\begin{array}{l}\text { In my opinion, English language is difficult and } \\
\text { complicated to learn. }\end{array}$ & 180 & 1 & 5 & 2.82 & 1.211 & 1.465 \\
\hline $\begin{array}{l}\text { English subject has the content that covers many fields of } \\
\text { knowledge. }\end{array}$ & 180 & 1 & 5 & 2.54 & 1.005 & 1.009 \\
\hline Valid N & 180 & & & & & \\
\hline
\end{tabular}

Table 5. Descriptive Statistics of Emotional Aspect of Language Attitude

\begin{tabular}{|c|c|c|c|c|c|c|}
\hline Emotional aspect of attitude & $\mathrm{N}$ & Min & Max & Mean & $\begin{array}{l}\text { Std. } \\
\text { Deviation }\end{array}$ & Variance \\
\hline I feel proud when studying English language. & 180 & 1 & 5 & 2.47 & 1.059 & 1.122 \\
\hline I feel excited when I communicate in English with others. & 180 & 1 & 5 & 2.30 & 1.083 & 1.172 \\
\hline $\begin{array}{l}\text { I don't get anxious when I have to answer a question in my } \\
\text { English class. }\end{array}$ & 180 & 1 & 5 & 2.83 & 1.006 & 1.011 \\
\hline Studying foreign languages like English is enjoyable & 180 & 1 & 5 & 2.32 & 1.001 & 1.002 \\
\hline To be inquisitive makes me study English well. & 180 & 1 & 5 & 2.93 & 1.293 & 1.672 \\
\hline $\begin{array}{l}\text { Studying English makes me have good emotions } \\
\text { (feelings). }\end{array}$ & 180 & 1 & 5 & 2.71 & 1.038 & 1.078 \\
\hline $\begin{array}{l}\text { I prefer studying in my mother tongue rather than any } \\
\text { other foreign language. }\end{array}$ & 180 & 1 & 5 & 3.81 & 1.157 & 1.338 \\
\hline I enjoy doing activities in English. & 180 & 1 & 5 & 2.78 & 1.100 & 1.210 \\
\hline I do not like studying English. & 180 & 1 & 5 & 2.33 & 1.195 & 1.428 \\
\hline I wish I could speak English fluently. & 180 & 1 & 5 & 1.94 & 1.045 & 1.092 \\
\hline I am interested in studying English. & 180 & 1 & 5 & 2.41 & 1.122 & 1.259 \\
\hline Studying English subject makes me feel more confident. & 180 & 1 & 5 & 2.87 & 1.3929 & 1.940 \\
\hline $\begin{array}{l}\text { To be honest, I really have little interest in my English } \\
\text { class. }\end{array}$ & 180 & 1 & 5 & 2.52 & 1.141 & 1.301 \\
\hline Knowing English is an important goal in my life. & 180 & 1 & 5 & 2.31 & 1.154 & 1.333 \\
\hline I look forward to the time I spend in English class. & 180 & 1 & 5 & 2.56 & 1.037 & 1.075 \\
\hline Valid N & 180 & & & & & \\
\hline
\end{tabular}


Table 6. Descriptive Statistics of Attitude towards English by Gender

\begin{tabular}{llllll}
\hline & gender & $\mathrm{N}$ & Mean & Std. Deviation & Std. Error Mean \\
\hline attitude & female & 86 & 2.7599 & 0.54763 & 0.05905 \\
\cline { 2 - 6 } & male & 94 & 2.4856 & 0.60298 & 0.06219 \\
\hline
\end{tabular}

Table 7. Independent Samples T-test of Students' Attitude by Gender Variable

\begin{tabular}{|c|c|c|c|c|c|c|c|c|c|c|}
\hline & & \multicolumn{2}{|c|}{$\begin{array}{l}\text { Levene's Test } \\
\text { for Equality of } \\
\text { Variances }\end{array}$} & \multicolumn{5}{|c|}{ T-test for Equality of Means } & \multirow{2}{*}{\multicolumn{2}{|c|}{$\begin{array}{l}95 \% \text { Confidence } \\
\text { Interval of the } \\
\text { Difference }\end{array}$}} \\
\hline & & $\mathrm{F}$ & Sig. & $\mathrm{t}$ & $\mathrm{df}$ & $\begin{array}{l}\text { Sig. } \\
\text { (Tow- } \\
\text { tailed) }\end{array}$ & $\begin{array}{l}\text { Mean } \\
\text { Difference }\end{array}$ & $\begin{array}{l}\text { Std. Error } \\
\text { Difference }\end{array}$ & & \\
\hline \multirow[t]{2}{*}{$\begin{array}{l}\text { Total } \\
\text { attitude }\end{array}$} & $\begin{array}{l}\text { Equal } \\
\text { variances } \\
\text { assumed }\end{array}$ & 5.268 & 0.023 & 3.186 & 178 & 0.002 & 0.27437 & 0.08613 & 0.10440 & 0.44434 \\
\hline & $\begin{array}{l}\text { Equal } \\
\text { variances not } \\
\text { assumed }\end{array}$ & & & 3.199 & 177.992 & 0.002 & 0.27437 & 0.08576 & 0.10513 & 0.44361 \\
\hline
\end{tabular}

Table 8. Descriptive Statistics of Attitude towards English by Field of Study

\begin{tabular}{|c|c|c|c|c|c|c|c|c|}
\hline \multirow[t]{2}{*}{ ELA } & \multirow[b]{2}{*}{$\mathrm{N}$} & \multirow[b]{2}{*}{ Mean } & \multirow[b]{2}{*}{$\begin{array}{l}\text { Std. } \\
\text { Deviation }\end{array}$} & \multirow[b]{2}{*}{ Std. Error } & \multicolumn{2}{|c|}{$\begin{array}{l}95 \% \text { Confidence } \\
\text { Interval for Mean }\end{array}$} & \multirow[b]{2}{*}{ Minimum } & \multirow[b]{2}{*}{ Maximum } \\
\hline & & & & & $\begin{array}{l}\text { Lower } \\
\text { Bound }\end{array}$ & $\begin{array}{l}\text { Upper } \\
\text { Bound }\end{array}$ & & \\
\hline Basic Sciences & 55 & 2.4566 & 0.52877 & 0.07130 & 2.3136 & 2.5995 & 1.53 & 3.18 \\
\hline Life Sciences & 66 & 2.6357 & 0.64013 & 0.07879 & 2.4783 & 2.7931 & 1.24 & 3.73 \\
\hline Social Sciences & 59 & 2.7446 & 0.56557 & 0.07363 & 2.5972 & 2.8920 & 1.51 & 3.91 \\
\hline Total & 180 & 2.6167 & 0.59177 & 0.04411 & 2.5296 & 2.7037 & 1.24 & 3.91 \\
\hline
\end{tabular}

Table 9. Test of Homogeneity of Variances

\begin{tabular}{llll}
\hline Levene Statistic & df1 & df2 & Sig. \\
\hline 1.554 & 2 & 177 & 0.214 \\
\hline
\end{tabular}

Table 10. ANOVA Test

\begin{tabular}{llllll}
\hline & Sum of Squares & df & Mean Square & F & Sig. \\
Between Groups & 2.400 & 2 & 1.200 & 3.523 & 0.032 \\
Within Groups & 60.286 & 177 & 0.341 & & \\
\hline Total & 62.685 & 179 & & & \\
\hline
\end{tabular}


Table 11. Multiple Comparison Test

\begin{tabular}{lllllll}
\hline \multirow{3}{*}{ (I) field } & \multicolumn{3}{c}{$\begin{array}{l}\text { Mean } \\
\text { Difference }\end{array}$} & & \multicolumn{2}{c}{$95 \%$ Confidence Interval } \\
\cline { 4 - 7 } Basic Sciences & Life Sciences & -0.17912 & 0.10655 & 0.215 & -0.4310 & 0.0727 \\
\cline { 2 - 7 } & Social Sciences & $-0.28807^{*}$ & 0.10939 & 0.025 & -0.5466 & -0.0295 \\
\hline Life Sciences & Basic Sciences & 0.17912 & 0.10655 & 0.215 & -0.0727 & 0.4310 \\
\cline { 2 - 7 } Social Sciences & Social Sciences & -0.10894 & 0.10456 & 0.551 & -0.3561 & 0.1382 \\
& Basic Sciences & $0.28807^{*}$ & 0.10939 & 0.025 & 0.0295 & 0.5466 \\
\cline { 2 - 7 } & Life Sciences & 0.10894 & 0.10456 & 0.551 & -0.1382 & 0.3561
\end{tabular}

*The mean difference is significant at the 0.05 level.

Table 12. Descriptive Statistics of English Language Attitude by Year of Study

\begin{tabular}{|c|c|c|c|c|c|c|c|c|}
\hline \multirow[t]{2}{*}{ ELA } & \multirow[b]{2}{*}{$\mathrm{N}$} & \multirow[b]{2}{*}{ Mean } & \multirow{2}{*}{$\begin{array}{l}\text { Std. } \\
\text { Deviation }\end{array}$} & \multirow{2}{*}{ Std. Error } & \multicolumn{2}{|c|}{$\begin{array}{l}95 \% \text { Confidence Interval for } \\
\text { Mean }\end{array}$} & \multirow[b]{2}{*}{ Minimum } & \multirow[b]{2}{*}{ Maximum } \\
\hline & & & & & Lower Bound & Upper Bound & & \\
\hline First year & 58 & 2.6985 & 0.51455 & 0.06756 & 2.5632 & 2.8338 & 1.24 & 3.82 \\
\hline Second year & 68 & 2.5941 & 0.55893 & 0.06778 & 2.4588 & 2.7294 & 1.51 & 3.62 \\
\hline Third year & 54 & 2.5572 & 0.70107 & 0.09540 & 2.3658 & 2.7486 & 1.24 & 3.91 \\
\hline Total & 180 & 2.6167 & 0.59177 & 0.04411 & 2.5296 & 2.7037 & 1.24 & 3.91 \\
\hline
\end{tabular}

Table 13. Test of Homogeneity of Variances

\begin{tabular}{llll}
\hline Levene Statistic & df1 & df2 & Sig. \\
\hline 4.807 & 2 & 177 & 0.009 \\
\hline
\end{tabular}

Table 14. ANOVA Test

\begin{tabular}{llllll}
\hline & Sum of Squares & df & Mean Square & F & Sig. \\
\hline Between Groups & 0.614 & 2 & 0.307 & 0.875 & 0.419 \\
\hline Within Groups & 62.072 & 177 & 0.351 & & \\
\hline Total & 62.685 & 179 & & & \\
\hline
\end{tabular}

